\title{
Author Index Volume 13
}

Abdunnur, L., see Griffin, T.

Albert, J. and Amor, P., Multi-country pilot projects: a quantum leap in Eurostat's statistical assistance to Central and Eastern Europe

Amor, P., see Albert, J.

Andrianasolo, R., see Griffin, T.

Arts, C.H., Integration at the micro level of data on persons receiving national assistance benefits

Baldacci, E. and Lugaresi, S., Assessing the impact of demographic ageing on the welfare state in Italy. A dynamic simulation

Bernelot Moens, W.E., Household actual final consumption in the Netherlands

Carter, R. and McClean, K., Using administrative data in the Canadian Census: experiences and plans

Church, J., World Summit for Social Development: implications for statistics

Davidoff, L., Police performance indicators

Dumitrescu, I., see Radocea, A.

Dysterud, M.V. and Rogstad, L., Land use statistics for cities and urban agglomerations: development of a method based on administrative records and the use of geographical information systems

Fellegi, I.P., Characteristics of an effective statistical system

Flatt, A., see Griffin, T.

Gilomen, H., Education and social mobility. Insights into the Swiss situation

Glaude, M., Guest-editorial

Goux, D. et Maurin, E., Méritocratie et hérédité sociale en France. Une étude à partir des enquêtes sur la Formation et la Qualification Professionnelle (FQP), 1970, 1977, 1985, 1993 
Griffin, T., The relationship of the United Nations Economic Commission for Europe (UN/ECE, Geneva) to the Organization for Economic Cooperation and Development (OECD, Paris) and the Statistical Office of the European Communities (Eurostat, Luxembourg)

Griffin, T. and Scott, W., Helping countries in transition with social and demographic statistics: the ECE/UNDP project

Griffin, T., Andrianasolo, R., Sainz, P., Flatt, A. and Abdunnur, L., Strengthening the role of the regional Commissions in statistics

Harala, R. and Vihavainen, H., Intergenerational distribution and inheritance:

welfare and social mobility - Finnish experience

Harala, R. and Reinikainen, A.-L., Confidentiality in the use of administrative data sources

Hoffmann, E., Requirements and possible sources for statistics on the dynamics of employment: a producer perspective

Lendvai, J., Statistics of transition, transition in statistics: the Hungarian experience

Lugaresi, S., see Baldacci, E.

Macura, M., Fertility and nuptiality changes in Central and Eastern Europe: 1982-1993

Maurin, E., see Goux, D.

McClean, K., see Carter, R.

Mikkelsen, L., Focus on the 44th plenary of the Conference of European Statisticians

Nordbotten, S., Editing and imputation by means of neural networks

Priest, G., Challenges and opportunities in administrative records

Radocea, A., Dumitrescu, I. and Stefanescu, D., Recent developments of statistical approach reflecting the macroeconomic equilibrium

Reinikainen, A.-L., see Harala, R.

Rogstad, L., see Dysterud, M.V.

Rose, D., The ESRC review of UK government social classifications

Ryten, J., Management training and development in Statistics Canada 
Sainz, P., see Griffin, T.

Sarossy, G., Social mobility in a post industrial society: the role of an occupation classification and its required attributes

Scott, W., see Griffin, T.

Smith, W., Seducing the gatekeepers: Statistics Canada's Daily and the news media

Stefanescu, D., see Radocea, A.

Stibbard, P., Data describing labour market dynamics: can we do better?

Vihavainen, H., see Harala, R. 